\title{
Investigation of Different Morphometric Attributes And The Find out Erosional Surfaces As Well As Stage of Evolution of Daluaghat Drainage Basin In Giridih District, Jharkhand, India
}

\author{
Sumitra Mandi*1 Kalicharan Soren*2 \\ ${ }^{1}$ Assistant Teacher, Birendranagar High School, Hooghly - 712102 (W.B.) India \\ ${ }^{* 2}$ Lab.attendent, School of water resource Engg. Jadavpur university Kol -700032(W.B.) India \\ *1mandisumitra@gmail.com*2 kalicharansoren52@gmail.com
}

\begin{abstract}
A main importance in geomorphology over the past quite a few decades has been on the development of quantitative physiographic methods to illustrate the development and activities of surface drainage networks. The quantitative analysis of morphometric parameters is found to be of enormous convenience in river basin evaluation. The influence of drainage morphometry is extremely noteworthy in understanding the landform processes, soil physical properties and erosional characteristics. Drainage characteristics of several river basins and sub-basins in different parts of the globe have been deliberate using conventional methods. Modern statistical analysis and Geographical Information System (GIS) techniques are now-a-day used for assessing different landscape and morphometric parameters of the drainage basins as they endow with a elastic surroundings and a influential device for the manipulation and analysis of spatial information. In the present study, stream number, order, frequency, density and bifurcation ratio are derivative and calculated on the basis of areal and linear properties of drainage channels using GIS based on drainage lines of Daluaghat Drainage Basin of Giridih, Jharkhand as represented over the topographical map no 72 L/8 (R.F. 1:50,000). Area-altitudinal correlation also is assessed in this work to recognize the erosional surfaces as well as stage of development. in addition, in this study try to investigate different morphometric attributes and set up correlation between the dependent and independent variables through Principal component analysis to recognize the major morphometric parameters which has a remarkable function in the erosional landforms of this drainage basin.
\end{abstract}

Keywords - Morphometric attributes; GIS; quantitative analysis; Area-altitudinal correlation; PCA; erosional surface; stage of development.

\section{INTRODUCTION}

After Second World War the chief methodological shift in Geomorphology was characterized by the manifestation of quantitative geomorphology as a significance of relevance of statistical and mathematical methods to the study of landform and process. In the practical Theory of geomorphological discipline, analysis of the interrelationship between forms (landforms) of medium to small spatial scale relating rapid sequential changes $a^{\mathrm{i}} \mathrm{d}$ geomorphic processes and other landform Scheming factors became the important theme. But the compulsory information of rapid secular change to authenticate efficient interaction was not forthcoming. Thus the functional theory has depended on the competency of statistical and mathematical methods. [1]

From this study, we are making an effort to decide the erosional landforms and attempt to evaluate the stages of erosion of Daluaghat Drainage Basin.

\section{OBJECTIVES OF THE STUDY AREA}

Despite the fact that, there are immeasurable techniques of morphometric and hydrological analysis in this study, only a large amount extensively exploit techniques are discussed because these are the 
fundamental factors of any type of basin morphometry. These are A. Stream Hierarchy (Stream ordering and Bifurcation ratio and Length ratio), B. Areal features (Form Factor, Shape Factor, Circularity ratio, elongation ratio) and C. Relief and Slope factors( Relative Relief, Average Slope, Dissection Index, Ruggedness index, Drainage Density). To investigation all of the variables, a micro-level basin (46.02 $\mathrm{km}^{2}$ ) have been selected because these morphometric analysis are closely related with the enthusiasm of small drainage basin.

- To evaluate the geomorphological consequence, the most important objectives are as follows:

- To evaluate the physical features and climatic condition of this basin and adjacent areas.

- To Investigate the linear, areal and relief aspects of fluvial morphometry.

- Find out the area-altitudinal correlation to classify the erosion surfaces and stages of development.

- Development the different practical relations between the different morphometric parameters through PCA analysis and testing these practical relations.

- Identifying the overriding morphometric factors in the growth as well as evolution of Basin features.

\section{METHODS \& TECHNIQUES}

This effort involves three main processes- observation, recording or gathering and Interpretation or analysis. In the first step, base map is prepared based on Topographical Sheet Number $72 \mathrm{~L} / 8$ published by Survey of India with scale 1: 50,000. In this phase, Basin has been demarcated with the help of MapInfo-11.0 software. Basin area and length of the basin have been recorded. Then to identify with the stream hierarchy of linear network, method proposed by A.N.Strahler (1952) of Stream Ordering have been followed, then bifurcation ratio, length also be calculated. Then to identify the relief and slope feature, the whole of Basin area has been divided into 67 one square $\mathrm{km}$ grid. Then maximum and minimum values of elevation, number of contour crossing and drainage frequency and the total length of the streams in each grid have been recorded. Different indices have been used to represent the linear, areal, relief and slope features in this drainage basin.

Microsoft Excel 2007 and XL STAT 2016 software to use enumerates the data analysis. MapInfo-11.0 software has helped in the preparation of different thematic maps.

The whole study area is based on secondary information and the information recorded from the Topographical Sheet No.72 L/8 (1:50, 000) published by Survey of India. For this reason, to accumulate the basic information about the Giridih District, Jharkhand official website of this district has been retrieved. Different journals and literature have also been studied in this purpose for basic understanding.

\section{Location of Study Area}

The Daluaghat Drainage Basin is a 5th order river basin NE-SW orientation and areal coverage is $46.02 \mathrm{Km}^{2}$. which is a tributary of Barakar River flowing along the left bank of Barakar River. The entire Basin is 
placed in the Lower Hazaribagh Plateau. Longitudinal extension of this Basin ranges from $86^{\circ} 23^{\prime}$ E to $86^{\circ} 27^{\prime}$ $\mathrm{E}$ and latitudinal extension ranges from $24^{\circ} 18^{\prime} \mathrm{N}$ to $24^{\circ} 23^{\prime} \mathrm{N}$. Barakar River traverses the basin from North west - south east direction. Through, the metalled road passes along the lower portion of the Daluaghat Drainage Basin.

\section{RESULTS AND DISCUSSIONS}

\subsection{Climatic condition of the study area}

The study area has a stunning climate. For five to six months of the year, from October onward the days are sunny and refreshing. The mean temperature in December is $23{ }^{\circ} \mathrm{C}$. The nights are cold and temperatures in winter may fall below freezing point in many places. In April and May being hottest when temperature rises up to $47^{\circ} \mathrm{C}$ but it is very dry and not oppressive as in the neighboring plains. The rainy season (June to September) is pleasurable. The Chotanagpur Plateau receives an annual average rainfall of around 1,400 millimeters (55 in), which is less than the rain forested areas of much of India and almost all of it in the monsoon months between June and August.

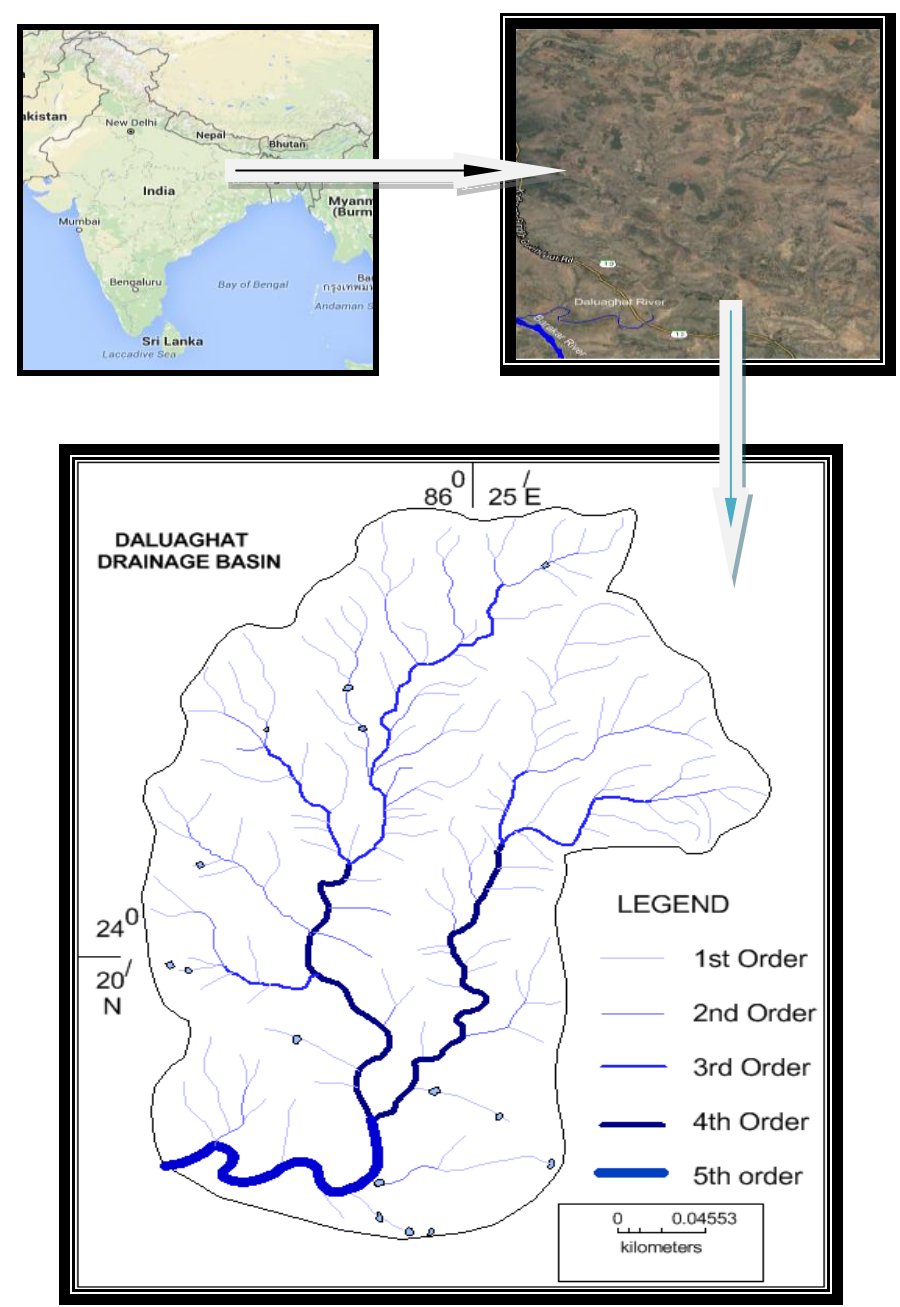


Figure: 1 Location map of the study area.

5.2 Physical settings of the study area

- The study area has several unique as well as special physical features and climatic conditions with respect to Lower Hazaribagh Plateau and Barakar Basin.

- The study area belongs to ancient Archaean formation (Granite and Gneiss) with some patches of Dharwar rocks consist of Mica Schist and Phyllite.

- Humid wet dry type of climate with mean monthly temperature is ranging between $29^{\circ} \mathrm{C}$ to $32^{\circ} \mathrm{C}$ and annual rainfall ranges from 100 to above $150 \mathrm{~cm}$.

- Daluaghat drainage Basin is covered under dry deciduous forest, mainly peninsular Sal, Mahua, Palas, Asan and Scrubs etc.

- Most essential processes: Severe physical weathering (mainly Exfoliation), fluvial erosion, gully erosion, local metamorphism of plutonic igneous rocks, e.g., Granite etc.

5.3 Linear aspects of the drainage system

Table1 Linear aspects of the study area

\begin{tabular}{|c|c|c|c|c|c|c|c|c|c|}
\hline River Basin & $\begin{array}{l}\text { Stream } \\
\text { order }\end{array}$ & $\begin{array}{l}\text { Tot } \\
\text { stre } \\
\text { (Ne }\end{array}$ & $\begin{array}{l}\text { al no. of } \\
\text { am } \\
\text { ) }\end{array}$ & \multicolumn{2}{|c|}{$\begin{array}{l}\text { Total Stream } \\
\text { length(Lu) }\end{array}$} & $\begin{array}{l}\text { Mean Stream } \\
\text { length (Lsm) }\end{array}$ & $\begin{array}{l}\text { Stream } \\
\text { length } \\
\text { ratio }\end{array}$ & $\begin{array}{l}\text { Log } \\
\mathrm{Nu}\end{array}$ & Log Lu \\
\hline \multirow{5}{*}{ Daluaghat } & $1^{\text {st }}$ & & 123 & \multicolumn{2}{|c|}{4.74} & 0.04 & & 2.08 & 0.67 \\
\hline & 2nd & & 24 & \multicolumn{2}{|c|}{2.95} & 0.12 & 3 & 1.38 & 0.46 \\
\hline & $3 r d$ & & 5 & \multicolumn{2}{|c|}{2.56} & 0.51 & 4.25 & 0.69 & 0.41 \\
\hline & 4th & & 2 & \multicolumn{2}{|c|}{2.072} & 1.03 & 2.02 & 0.30 & 0.32 \\
\hline & 5 th & & 1 & \multicolumn{2}{|c|}{1.814} & 1.82 & 1.76 & 0 & 0.25 \\
\hline \multicolumn{2}{|c|}{ Total } & & 155 & \multicolumn{2}{|c|}{ Total=13.4 } & & & & \\
\hline \multicolumn{6}{|c|}{ Bifurcation Ratio (Rb) } & & & & \\
\hline $\begin{array}{l}\text { 1st Order / } \\
\text { 2nd Order }\end{array}$ & \multicolumn{2}{|c|}{$\begin{array}{l}\text { 2nd Order / } \\
\text { 3rd Order }\end{array}$} & \multicolumn{2}{|c|}{$\begin{array}{l}\text { 3rd Order / 4th } \\
\text { Order }\end{array}$} & $\begin{array}{l}\text { 4th } \\
\text { Order / } \\
5 \text { th } \\
\text { Order }\end{array}$ & \multicolumn{4}{|c|}{ Mean Bifurcation Ratio } \\
\hline 5.125 & \multicolumn{2}{|l|}{4.8} & \multicolumn{3}{|l|}{2.5} & \multicolumn{4}{|c|}{3.61} \\
\hline
\end{tabular}

In morphometric analysis the first step is find out stream ordering following the methods by A.N.Strahler (1952) is used. There are five order of linear stream channel can be recognized in this study area. 


\subsection{Aerial and relief aspects of the drainage system.}

Areal properties convey the taken as a whole preparation appearance and magnitude of drainage basin (Summerfield; 1991). The ideal drainage basin is generally of pear shape but it is reliant on the size and the length of the master stream of the basin and basin perimeter which are reliant of relief, slope, geology and lithological characteristics of the basin. The Areal aspects such as form factor, elongation ratio, circularity ratio and Lemniscate ratio of Daluaghat Drainage Basin undoubtedly exposed that the whole basin is oval in character. The relief aspects determined take in relief ratio, relative relief and ruggedness number.

\subsection{Identification of geomorphic stage of drainage basin}

Find out the geomorphic stages and erosional surfaces in any drainage basin has been supplementary suitably concluded by the investigation of area-altitude correlation in general and hypsometric analysis in particular. As a result of assessing individual altitude zones all along with corresponding areal coverage, this hypsometric curve is meaningful of youthful, mature and senile topography. The longitudinal profile of Daluaghat Drainage Basin that there is one nick points which indicates Stages of development (Figure 4).

Table: 2 Aerial and relief aspects of the study area

\begin{tabular}{|c|c|c|c|}
\hline Sl.no & Morphometric parameters & Symbol /Formula & Result \\
\hline $\mathbf{1}$ & Relief ratio (Rr) & $\mathrm{Rr}=\mathrm{H} / \mathrm{Lb}$ & 15.58 \\
\hline $\mathbf{2}$ & Basin relief (R) & $\mathrm{R}=\mathrm{Max}-\mathrm{Min}$ & 152 \\
\hline $\mathbf{3}$ & Dissection index & $\mathrm{R} / \mathrm{Max}$ & 0.74 \\
\hline $\mathbf{4}$ & Ruggedness index (RI) & $\mathrm{RI}=\mathrm{R} \times \mathrm{Dd}$ & 4.52 \\
\hline $\mathbf{5}$ & Drainage density (Dd) & $\mathrm{Dd}=\mathrm{Lu} / \mathrm{A}$ & 0.29 \\
\hline $\mathbf{6}$ & Stream frequency (Fs) & $\mathrm{Fs}=\mathrm{Nu} / \mathrm{A}$ & 3.36 \\
\hline $\mathbf{7}$ & Texture ratio $(\mathrm{Tr})$ & $\mathrm{Nu} / \mathrm{P}$ & 5.13 \\
\hline $\mathbf{8}$ & Form factor $(\mathrm{Ff})$ & $\mathrm{Ff}=\mathrm{A} / \mathrm{Lb}$ & 0.48 \\
\hline $\mathbf{9}$ & Circulatory ratio $(\mathrm{Rc})$ & $\mathrm{Rc}=4 \times \prod \times \mathrm{A} / \mathrm{P}^{2}$ & 0.63 \\
\hline $\mathbf{1 0}$ & Elongation ratio $(\mathrm{Re})$ & $\mathrm{Re}=(4 \times \mathrm{A} / \Pi) 0.5 / \mathrm{Lb}$ & 0.78 \\
\hline $\mathbf{1 1}$ & Length of the overland flow $(\mathrm{Lo})$ & $\mathrm{Lo}=1 /(2 \times \mathrm{Dd})$ & 0.26 \\
\hline $\mathbf{1 2}$ & Compactness constant $(\mathrm{Cc})$ & $0.2821 \times \mathrm{P} / \mathrm{A} 0.5$ & 1.73 \\
\hline $\mathbf{1 3}$ & Compactness co- efficient & $\mathrm{P} / \mathrm{V} 2 \prod \mathrm{A}$ & 1.00 \\
\hline $\mathbf{1 4}$ & Infiltration number & $\mathrm{If}=\mathrm{Dd} \times \mathrm{Fs}$ & 0.97 \\
\hline $\mathbf{1 5}$ & Lemniscate ratio & $\mathrm{Lb} / 4 \mathrm{~A}$, & 0.52 \\
\hline
\end{tabular}

In this context hypsometric analysis may be the useful procedure to identify the erosional stage of this drainage basin (Table2). Area-altitude relationship clearly depicts the fact that major areal coverage i.e., $66.66 \%$ of this basin has the elevation of 220 to 280 meters. Whereas hypsometric integral (HI) value 0.12 Figure 5 (a) and 5(b). 


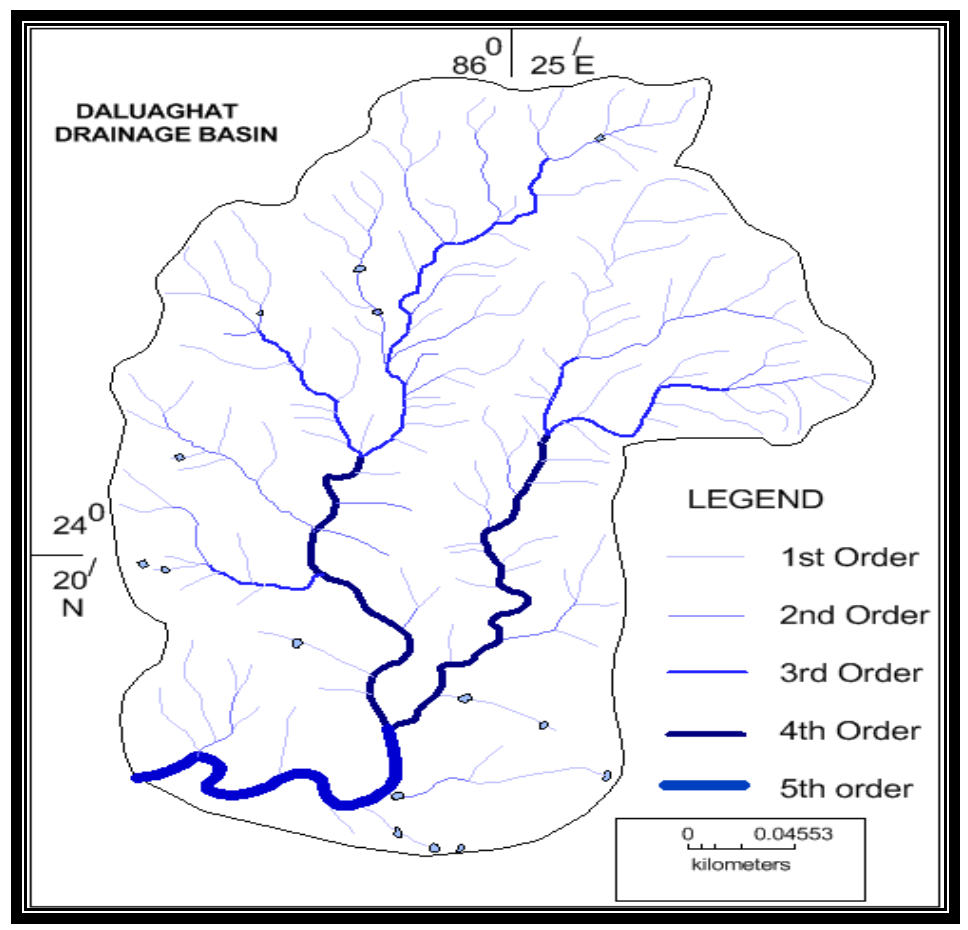

Figure: 2 Stream Ordering of Daluaghat Drainage Basin (Source: SOI Topographical Map 72L8)

\subsection{Multivariate analysis of different morphometric variables}

In Multivariate analysis main purpose is to find out the major factors of most important morphometric as well as hydrologic variables which are dependable for such type of development of this drainage basin. Because the morphometric and hydrologic variables do not work in separately but as strongly related

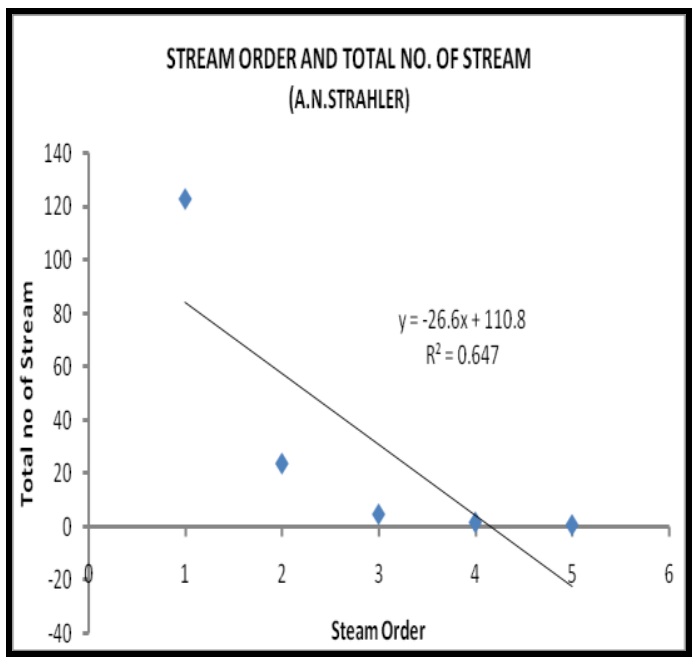

3(a)

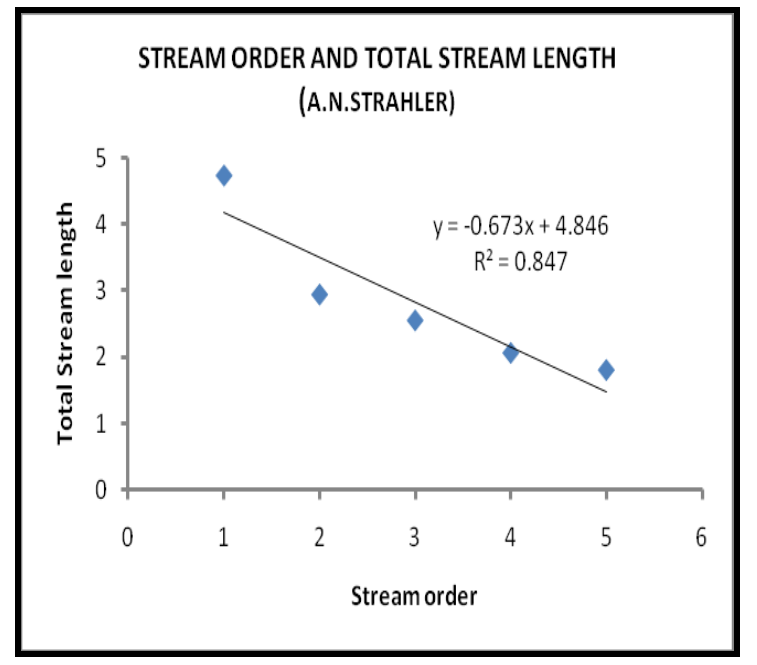

3(b) 
Figure: 3 (a) and (b) Relationship between Stream Order and Total no. Number Stream and

Total Stream Length

Table: 1 Calculation sheet for Hypsometric curve and Hypsometric Integral

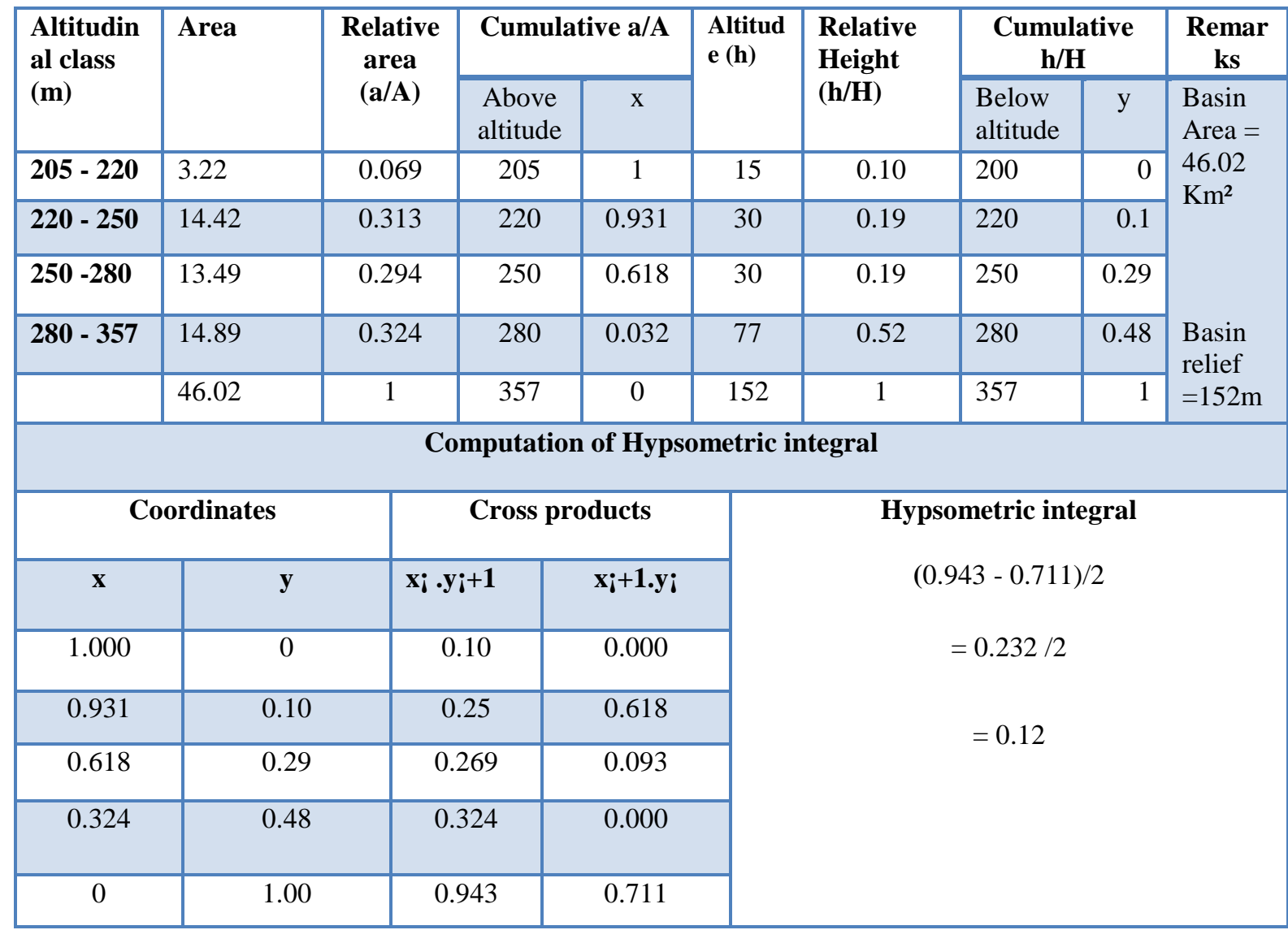

phenomena, a multivariate analysis seems to be quite essential to find out the qualified significance of each variable. Find out of Correlation Matrix and Principal Component Analysis (PCA) is the set of basic devices in this analysis. From the Correlation Matrix, we are able to easily find out the nature of bi - variate correlation of number of variables. The Principal Component Analysis provides the base of sorting out a number few components which relation for the major amount of explained variation of the variables. Rests of the components are of insignificant value. Again the consequence of the variables in order of their ranking can be done statistically through PCA .

Firstly, eight morphometric components are selected to arbitrator the erosional characteristics of the Basin based on grid data. all other components are interrelated with each other completely though relative relief, dissection index, average slope and ruggedness index are powerfully interrelated with each other With $41.43 \%$ 
explanation of 1st principal components Drainage Density turn out to be the chief determinant of drainage basin (Figure 7a and 7b).

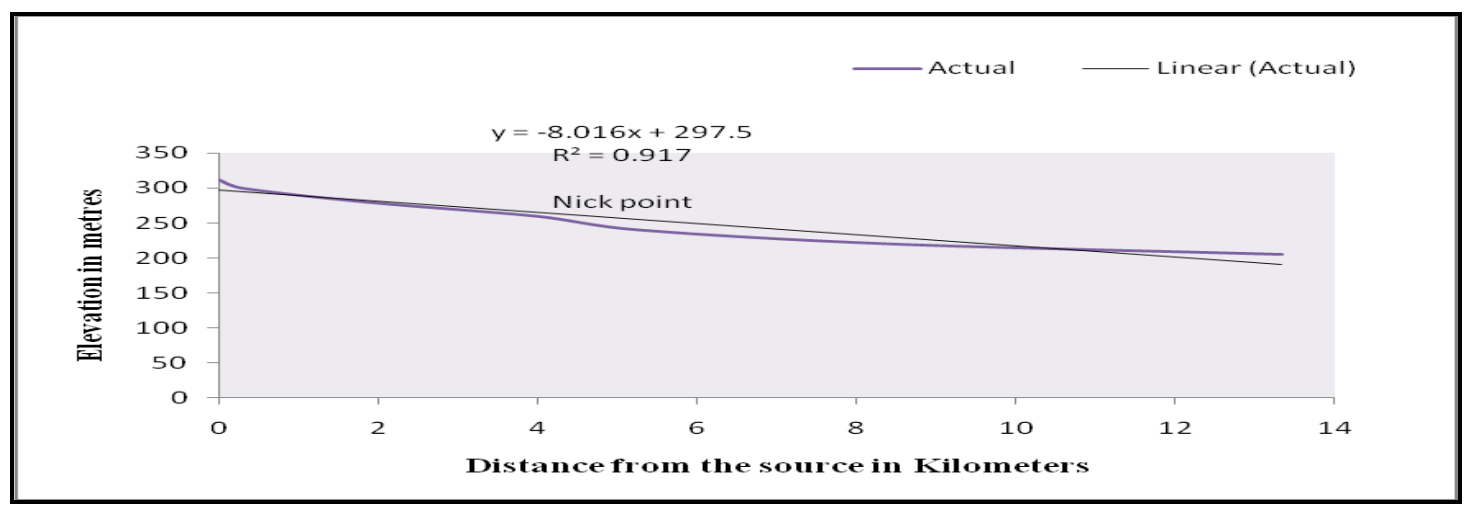

Figure 4: Longitudinal profile of Daluaghat drainage basin (Source: Toposheet 72 L/8)

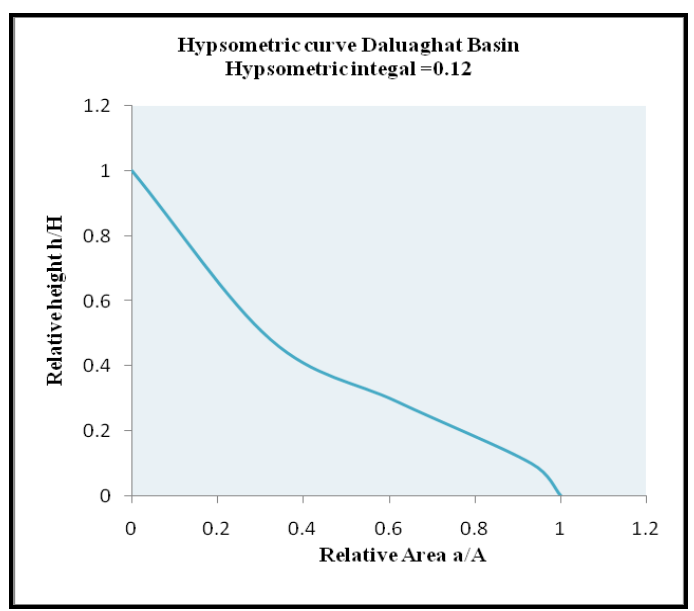

5(a)

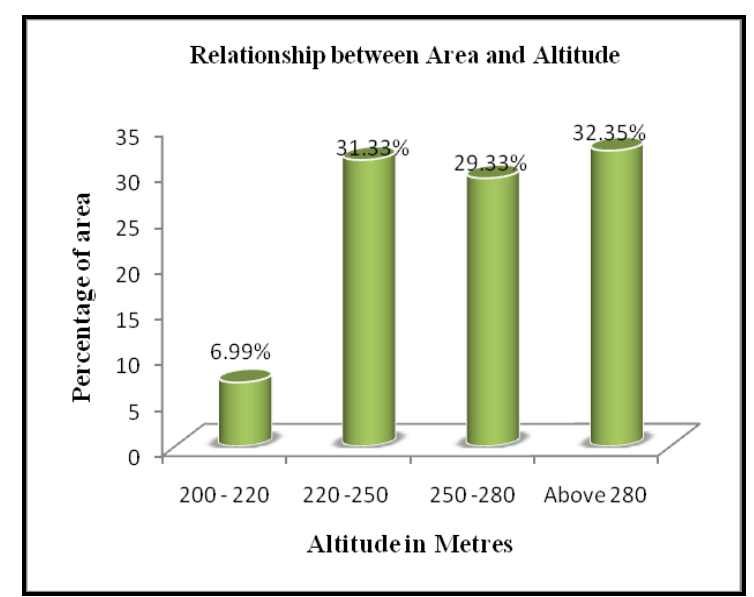

5(b)

Figures 5(a) \& 5(b) Hypsometric Curve of Daluaghat Basin and Relationship between Area and altitude.

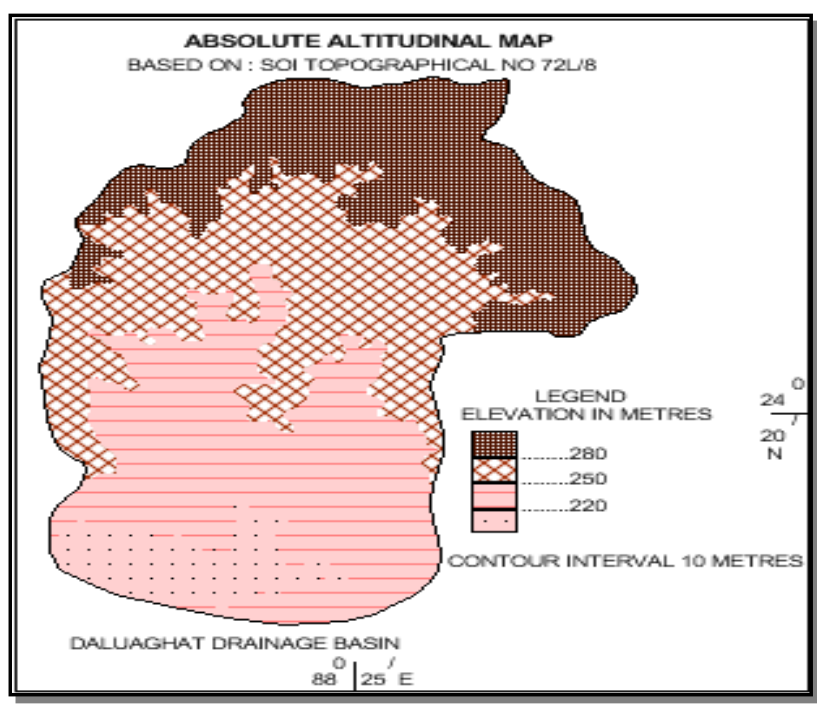


Figure 6: Absolute Altitude map of Daluaghat drainage basin

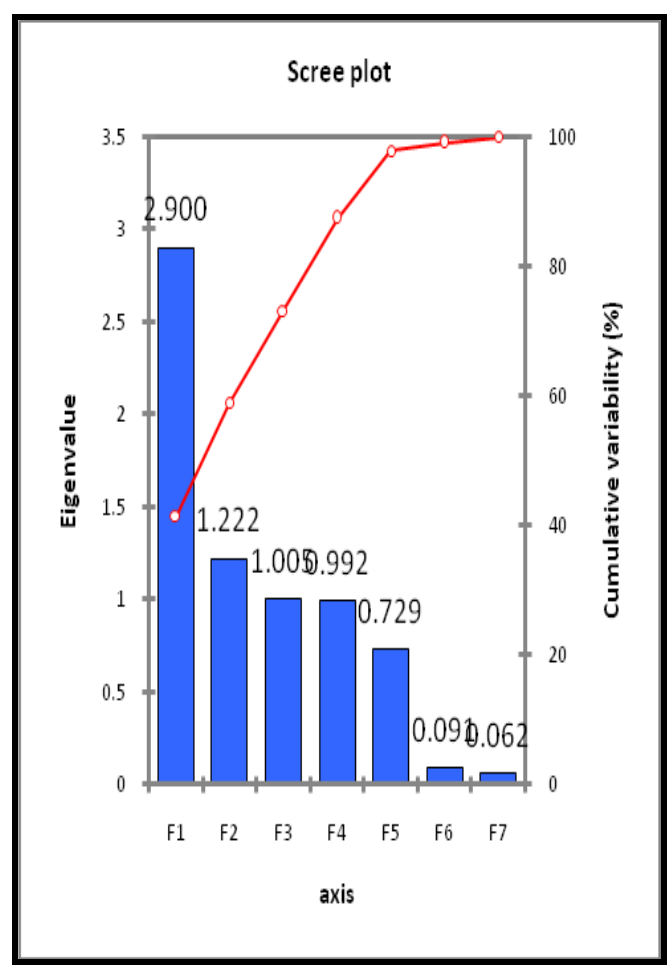

Figure 7 (a)

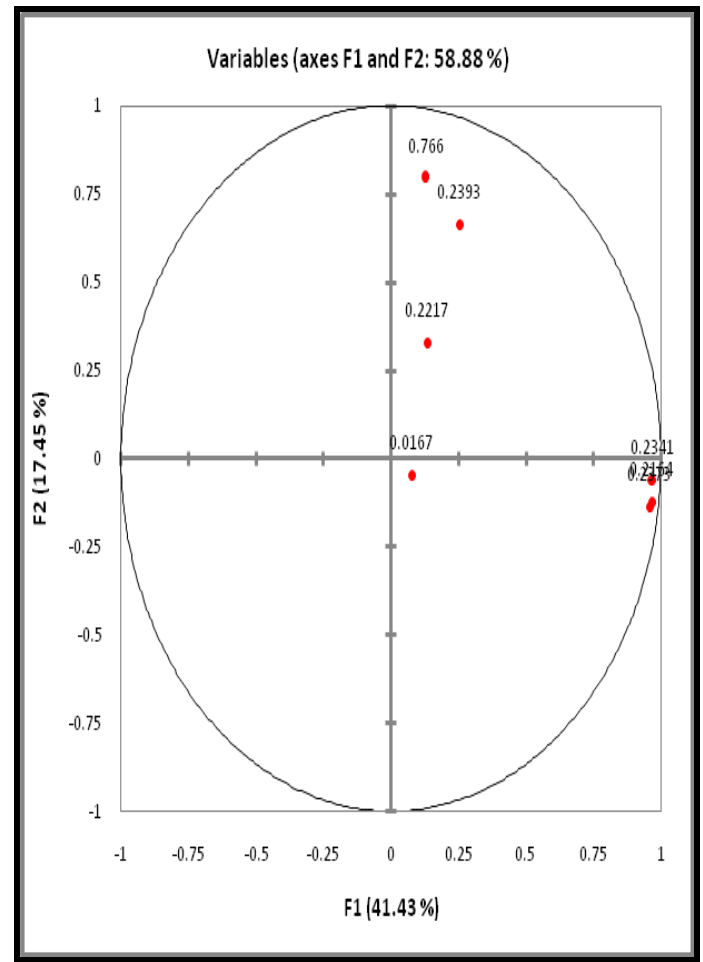

Figure $7(b)$

Table:3 Pearsonian product moment correlation matrix of Daluaghat drainage basin

\begin{tabular}{|c|c|c|c|c|c|c|c|c|}
\hline & RR & AS & DI & RI & Fs & DR & Dd & Ccm \\
\hline RR & 1 & 0.766 & 0.2393 & 0.2217 & 0.2373 & 0.2164 & 0.2341 & 0.0167 \\
\hline AS & & 1 & 0.236 & 0.1159 & 0.0465 & 0.0549 & 0.0701 & 0.02342 \\
\hline DI & & & 1 & 0.0124 & 0.12493 & 0.115247 & 0.2274 & -0.01973 \\
\hline RI & & & & 1 & 0.073379 & 0.113501 & 0.0616 & -0.00062 \\
\hline Fs & & & & & 1 & 0.9247 & 0.9041 & 0.061234 \\
\hline DR & & & & & & 1 & 0.9252 & 0.03231 \\
\hline Dd & & & & & & & 1 & 0.06145 \\
\hline Ccm & & & & & & & & 1 \\
\hline
\end{tabular}


$\mathrm{RR}=$ Relative Relief, $\mathrm{AS}=$ Average Slope, $\mathrm{DI}=$ Dissection Index, $\mathrm{RI}=$ Ruggedness Index, $\mathrm{DR}=\mathrm{Drainage}$ texture, Dd=Drainage Density, Fs= Stream Frequency, $\mathrm{Ccm}=$ Constant channel maintenance

Table: 4 Calculation sheet for Eigen values:

\begin{tabular}{|l|c|c|c|c|c|c|c|}
\hline & F1 & F2 & F3 & F4 & F5 & F6 & F7 \\
\hline Eigen value & 2.900 & 1.222 & 1.005 & 0.992 & 0.729 & 0.091 & 0.062 \\
\hline Variability (\%) & 41.433 & 17.450 & 14.350 & 14.165 & 10.416 & 1.296 & 0.889 \\
\hline Cumulative \% & 41.433 & 58.884 & 73.234 & 87.399 & 97.815 & 99.111 & 100.000 \\
\hline
\end{tabular}

\subsection{Test of significance of morphometric variables}

It is possible to infer whether the correlation coefficient of bi-variate normal population will be zero or not by using the test of significance of ' $r$ ' (product moment correlation coefficient). It is possible to conclude that whether the correlation is significant or not in this particular geo-climatic condition of Daluaghat Drainage Basin. Under the null hypothesis, that the population correlation is zero, the expression of the Student ${ }^{\prime} \mathrm{t}$ distribution with (n-2) degree of freedom is followed the equation:

$$
\mathbf{T}=\sqrt{ } \mathbf{r}^{2} \cdot(\mathbf{N}-2) /\left(\mathbf{1}-\mathbf{r}^{2}\right)
$$

Here as Drainage Density became the main factor for the development of Daluaghat Drainage Basin in PC1 (Table: 6) Then it has been considered as independent components and respite of the Factors are as

Table: 5 Calculation sheet for correlations between variables and factors

\begin{tabular}{|c|c|c|c|c|c|c|c|}
\hline & F1 & F2 & F3 & F4 & F5 & F6 & F7 \\
\hline RR & 0.128 & 0.795 & 0.096 & -0.068 & 0.581 & 0.000 & -0.002 \\
\hline DI & 0.254 & 0.665 & -0.286 & -0.329 & -0.550 & 0.021 & 0.018 \\
\hline RI & 0.136 & 0.327 & 0.454 & 0.774 & -0.264 & -0.001 & -0.010 \\
\hline SF & 0.959 & -0.136 & -0.010 & 0.009 & 0.057 & 0.229 & -0.072 \\
\hline DR & 0.967 & -0.124 & -0.014 & 0.061 & 0.062 & -0.043 & 0.199 \\
\hline DD & 0.969 & -0.062 & -0.045 & -0.041 & -0.005 & -0.189 & -0.131 \\
\hline CCM & 0.078 & -0.049 & 0.840 & -0.524 & -0.110 & -0.001 & 0.007 \\
\hline
\end{tabular}

dependent components. In these cases null hypothesis is rejected as the all computed values exceed the tabulated value in $1 \%$ significance level with degree of freedom 53. The correlation coefficients are 
enormously significant over a large number of related observations. Significance of ' $r$ ' is directly proportional to the degree of freedom, $n-2=53$. So, these variables are useful to decentralize the spatial variations of fluvial erosion.

Table 6: Computation and comparison of ' $t$ ' based on correlation coefficient of different morphometricVariables

\begin{tabular}{|c|c|c|c|c|}
\hline $\mathbf{X}$ & $\mathbf{Y}$ & $\mathbf{r}$ & Computed T & $\begin{array}{l}\text { Tabulated } \mathrm{T} \text { at } 53 \text { degrees of } \\
\text { freedom } 0.01 \text { Significance level }\end{array}$ \\
\hline \multirow{7}{*}{$\begin{array}{c}\text { Drainage } \\
\text { Density }\end{array}$} & Relative Relief & 0.2341 & 1.753 & \multirow[t]{7}{*}{ 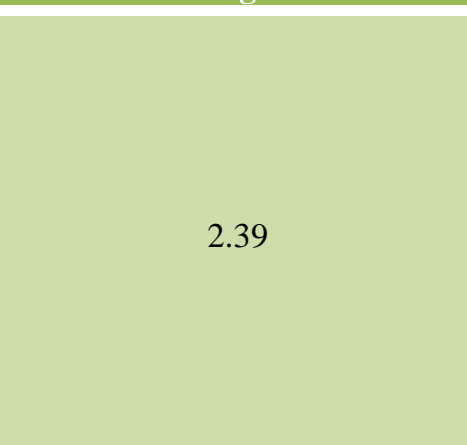 } \\
\hline & Dissection Index & 0.2274 & 1.700 & \\
\hline & Ruggedness Index & 0.0616 & 0.4493 & \\
\hline & Average Slope & 0.0701 & 0.5115 & \\
\hline & Stream Frequency & 0.9041 & 15.4028 & \\
\hline & $\begin{array}{l}\text { Constant channel } \\
\text { maintenance }\end{array}$ & 0.0614 & .04478 & \\
\hline & Drainage texture & 0.9252 & 17.7494 & \\
\hline
\end{tabular}

\section{CONCLUSIONS}

Use of different morphometric techniques on a small watershed is a well-organized method for categorize the land into different planning areas. From the classification of land design we can search out different small parts of that basin area and utilize them into different purposes. In this investigate, we are presently focus on the determination of erosional surface and its stage of evolution of the Daluaghat Drainage Basin. This investigate helps to identify which segment of land is under the useable condition for economically or residential as well as development zone. If we receive, this kind of small basin as a planning unit in plateau regions, we must be classifying those basins into different geomorphic area, i.e., hilly region, undulating plain, erosional plain and flood plain. On the other hand, from the evaluated stage of evolution, we can terminate the future possibility, in this situation there is a few spatial change take place or not. as well, the Daluaghat Drainage Basin belongs to senile or mature stage of evolution, which indicates this basin enclosed by planation surface and this area can used for any planning purpose.

\section{REFERENCE}

1. S. Singh, Geomorphology, Prayag Pustak Bhawan, Allahabad (2002).

2. A.N. Strahler, Quantitative geomorphology of drainage basins and channel networks In. Handbook of Applied Hydrology, McGraw Hill Book Company, New York, Section 4II, 1964

3. S.A Schumm, The evolution of drainage system and slopes in Badlands at Perth Amboy, New Jersey, Bulletin of Geological Society of America, 67,(1956) pp 214-236.

4. R.E Horton, Drainage basin characteristics, Trans. Amer. Geophys. U.14, (1932), pp 350-61.

5. R.E. Horton, "Erosional development of streams and their drainage basins: hydrophysical approach to quantitative morphology", Bull. Geol. Soc. Amer.,5 1945,pp 275-370.

6. K.G. Smith, , "Standards for grading texture of erosional topography”, Amer. Jour.Sci.,248, 1950 pp 655- 668 
7. V.C.Miller, "A quantitative geomorphic study of drainage basin characteristics in the Clinch Mountain area, Varginia and Tennessee", 1953, Project NR 389042,Tech. Rept.3.,Columbia University, Department of Geology, ONR, Geography Branch, New York.

8. Chorley,R.J., Donald,E.G., Malm., and Pogorzelski,H.A., “A new standard for estimating drainage basin shape”, Amer. Jour. Sci.,255, 1957, pp 138141.

9. A Cilleux \& L Romani. Modern trends in geomorphological; vol 1 Ed by Sharma, Concept pub. New Delhi (1982) pp 9 -19.

10. R. J. Chorley, S. A Schumm,. And D.E., Sugden, Geomorphology, Methuen and Co. Ltd., London, (1985), pp 316-326.

11. S L. Dingman FLUVIAL HYDRAULICS Copyright $\odot 2009$ by Oxford University Press.

12. D. Knighton. Fluvial forms and processes A new perspective. Arnold publication (1998).

13. L.B Leopold, M.G Wolman and J.P.Miller, Fluvial processes in geomorphology, Eurasia Publishing House, New Delhi. (1969).

14. A. Miller, the skin of the earth. Methuen \& Co. Ltd., London (1953).

15. M. Morisawa, Rivers-forms and process, Longman group, London, (1985), pp 54-56 and 70-73.

16. P.K Sen., Geomorphological analysis of drainage basins, the University of Burdwan, Burdwan (1993).

17. R.L Singh, India-a regional geography, National geographical society of India, Varanasi. (2008).

18. M.A Summerfield, Global geomorphology, Prentice Hall, New Delhi, (1991), pp 208-212.

19. S. Ghosh. Geomorphic land evaluation for sustainable use of lands resource in Puruliya district, W. B. Journal of landscape systems and ecological studies, 2012(June) vol.35 (1). pp. 263 -274.

20. N.S Magesh and N. Chandrasekar. And J.Arab GIS model-based morphometric evaluation of Tamiraparani subbasin, Tirunelveli district, Tamil Nadu, India DOI 10.1007/s12517-012-0742- Geosci $z$ @ Saudi Society for Geosciences 2012. 